$\begin{array}{ll}\text { Abstracta Iranica } & \begin{array}{l}\text { Abstracta Iranica } \\ \text { Revue bibliographique pour le domaine irano-aryen }\end{array} \\ & \text { Volume } \mathbf{2 8} \mid \mathbf{2 0 0 7} \\ & \text { Comptes rendus des publications de } \mathbf{2 0 0 5}\end{array}$

\title{
Sadr al-dîn Shîrâzî - La filosofia islamica y el problema del ser. Grenade, EUG, 2005, 230 p.
}

\section{Pierre Lory}

\section{(2) OpenEdition}

1 Journals

Édition électronique

URL : http://journals.openedition.org/abstractairanica/13612

DOI : 10.4000/abstractairanica.13612

ISSN : 1961-960X

Éditeur :

CNRS (UMR 7528 Mondes iraniens et indiens), Éditions de l'IFRI

\section{Édition imprimée}

Date de publication : 15 mai 2007

ISSN : 0240-8910

\section{Référence électronique}

Pierre Lory, «Sadr al-dîn Shîrâzî - La filosofia islamica y el problema del ser. Grenade, EUG, 2005, 230 p. », Abstracta Iranica [En ligne], Volume 28 | 2007, document 307, mis en ligne le 18 septembre 2007, consulté le 25 septembre 2020. URL : http://journals.openedition.org/abstractairanica/13612 ; DOI : https://doi.org/10.4000/abstractairanica.13612

Ce document a été généré automatiquement le 25 septembre 2020.

Tous droits réservés 


\section{Sadr al-dîn Shîrâzî - La filosofia islamica y el problema del ser. Grenade, EUG, 2005, 230 p.}

Pierre Lory

1 Ce travail fournit une présentation analytique du Ketāb al-mašă $\bar{c}^{\iota}$ r de Mollā Șadrā. Mais en fait, cette analyse proprement dite est précédée d'un exposé introductif très conséquent sur l'histoire de la philosophie en Islam et la façon dont elle a été escamotée par l'histoire générale de la philosophie en Occident. De même, les travaux des orientalistes sur la falsafe sont évoqués, et notamment la découverte, assez lente et progressive, de l'œuvre monumentale de Șadr al-dīn Šīrāzī; avec bien sûr un arrêt particulier sur l'apport de Henry Corbin. De ce fait, ce livre constitue en soi un petit survol du questionnement philosophique en Islam médiéval.

\section{INDEX}

Thèmes : 9. Philosophie

\section{AUTEURS}

PIERRE LORY

EPHE - Paris 